University of Nebraska - Lincoln

DigitalCommons@University of Nebraska - Lincoln

2009

\title{
Vulnerability of Rehabilitated Agricultural Production Systems to Invasion by Nontarget Plant Species
}

\author{
Sara G. Baer \\ Illinois University, Carbondale \\ David M. Engle \\ Oklahoma State University, david.engle@okstate.edu \\ Johannes M. H. Knops \\ University of Nebraska-Lincoln, jknops@unl.edu \\ Kenneth A. Langeland \\ University of Florida, kal@mail.ifas.ufl.edu \\ Bruce D. Maxwell \\ Montana State University, Bozeman \\ See next page for additional authors
}

Follow this and additional works at: https://digitalcommons.unl.edu/usgsnpwrc

Part of the Other International and Area Studies Commons

Baer, Sara G.; Engle, David M.; Knops, Johannes M. H.; Langeland, Kenneth A.; Maxwell, Bruce D.; Menalled, Fabian D.; and Symstad, Amy J., "Vulnerability of Rehabilitated Agricultural Production Systems to Invasion by Nontarget Plant Species" (2009). USGS Northern Prairie Wildlife Research Center. 127. https://digitalcommons.unl.edu/usgsnpwrc/127

This Article is brought to you for free and open access by the US Geological Survey at DigitalCommons@University of Nebraska - Lincoln. It has been accepted for inclusion in USGS Northern Prairie Wildlife Research Center by an authorized administrator of DigitalCommons@University of Nebraska - Lincoln. 


\section{Authors}

Sara G. Baer, David M. Engle, Johannes M. H. Knops, Kenneth A. Langeland, Bruce D. Maxwell, Fabian D. Menalled, and Amy J. Symstad 


\title{
Vulnerability of Rehabilitated Agricultural Production Systems to Invasion by Nontarget Plant Species
}

\author{
Sara G. Baer · David M. Engle · Johannes M. H. Knops · Kenneth A. Langeland • \\ Bruce D. Maxwell · Fabian D. Menalled · Amy J. Symstad
}

Received: 17 October 2007/ Accepted: 26 May 2008/Published online: 14 August 2008

(c) Springer Science+Business Media, LLC 2008 This article is a U.S. government work, and is not subject to copyright in the United States.

\begin{abstract}
Vast areas of arable land have been retired from crop production and "rehabilitated" to improved system states through landowner incentive programs in the United States (e.g., Conservation and Wetland Reserve Programs), as well as Europe (i.e., Agri-Environment Schemes). Our review of studies conducted on invasion of rehabilitated agricultural production systems by nontarget species elucidates several factors that may increase the vulnerability of these systems to invasion. These systems often exist in highly fragmented and agriculturally dominated landscapes, where propagule sources of target species for colonization may be limited, and are established under conditions where legacies of past disturbance persist and prevent target species from persisting. Furthermore,
\end{abstract}

\section{S. G. Baer $(\bowtie)$}

Department of Plant Biology and Center for Ecology, Southern

Illinois University, Carbondale, IL 62901-6509, USA

e-mail: sgbaer@siu.edu

D. M. Engle

Department of Natural Resource Ecology and Management, Oklahoma State University, Stillwater, OK, USA

\section{J. M. H. Knops}

School of Biological Sciences, University of Nebraska, Lincoln, NE, USA

\section{K. A. Langeland}

Agronomy Department, Center for Aquatic and Invasive Plants, University of Florida, Gainesville, FL, USA

B. D. Maxwell · F. D. Menalled

Land Resources and Environmental Science Department, Montana State University, Bozeman, MT, USA

\section{A. J. Symstad}

United States Geological Survey - Northern Prairie Wildlife Research Center, Black Hills Station, Rapid City, SD, USA rehabilitation approaches often do not include or successfully attain all target species or historical ecological processes (e.g., hydrology, grazing, and/or fire cycles) key to resisting invasion. Uncertainty surrounds ways in which nontarget species may compromise long term goals of improving biodiversity and ecosystem services through rehabilitation efforts on former agricultural production lands. This review demonstrates that more studies are needed on the extent and ecological impacts of nontarget species as related to the goals of rehabilitation efforts to secure current and future environmental benefits arising from this widespread conservation practice.

Keywords Agri-environment schemes .

Conservation programs · CRP · Invasive species .

Restoration

\section{Introduction}

Retiring arable lands from production and promoting perennial, native, and/or more diverse plant communities has become a widespread conservation practice to improve environmental quality (e.g., reduce soil erosion, increase water infiltration, reduce run-off of nutrients to surface water, improve soil quality, increase cover for wildlife, etc.) in agricultural landscapes of the United States (e.g., US Department of Agriculture [USDA] Conservation Reserve Program) and Europe (i.e., Agri-Environment Schemes [AES]). These lands, which we refer to as rehabilitated production systems (RPS), include arable systems that have been removed from agricultural production and "improved" through some conservation practice. These systems may differ from restorations, as Bradshaw (1996) explicitly defined rehabilitation as human facilitated 
recovery of some aspects of ecosystem structure (e.g., species diversity and complexity) and function (e.g., productivity, nutrient cycling), but not fully representative of the original system prior to human disturbance. Although rehabilitation goals of former agricultural production systems vary widely and practices invoked to achieve conservation goals can be antagonistic (Marrs and others 2007), both USDA programs and Agri-Environment Schemes generally aim to improve one or more aspects of ecosystem structure (e.g., plant diversity and/or dominant life forms) and/or function (e.g., soil stabilization, nutrient mitigation) (Dunn and others 1993; Anonymous 1994; Gibson 2009).

Thorough reviews of invasive species in natural systems (Mack and others 2000; Pimentel and others 2000; Pimentel 2002; Lodge and others 2006) demonstrate that invasions can change community, trophic, and/or physical structure, which in turn can result in cascading alterations to ecosystem functions (e.g., nutrient cycling and productivity [Vitousek and Walker 1989]) and landscape dynamics (e.g., fire and hydrologic regimes [D'Antonio and Vitousek 1992]). Although quantitative data are scarce, landowners and officials that monitor and administer programs for rehabilitating formerly cultivated lands recognize that many of these rehabilitations become colonized by nontarget species of concern (See Fig. 1). We define nontarget species as native and/or exotic species of concern, some of which are invasive, that can compromise the trajectory of community recovery and rehabilitation goals (D'Antonio and Meyerson 2002; Suding and others 2004). Despite the absence of literature on the extent to which RPS are colonized by nontarget species, numerous studies on the variety of factors influencing and ecological consequences of colonization and persistence of nontarget species in RPS

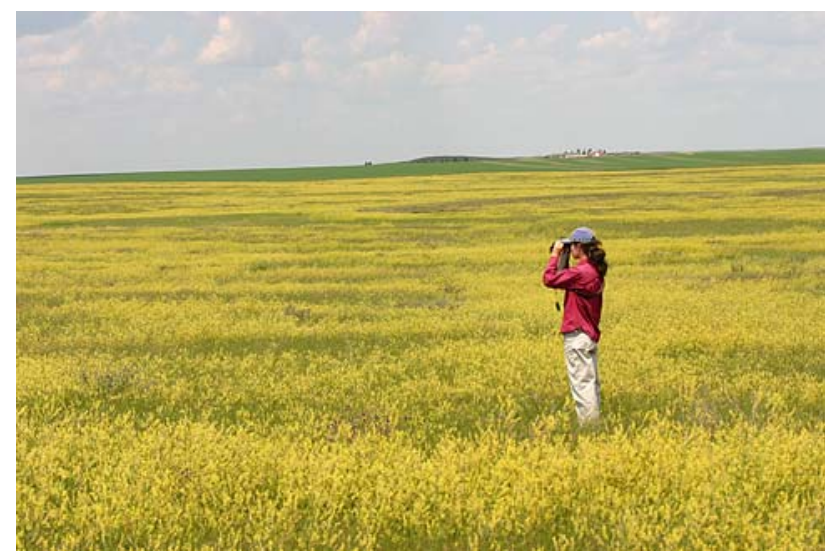

Fig. 1 A United States Geological Survey researcher surveying breeding birds in a CRP field planted to Agropyron cristatum (L.) Gaertn. (crested wheatgrass) and invaded by Melilotus officinalis (L.) Lam. (yellow sweetclover) in Sheridan County, Montana (photo by Lawrence D. Ig1)
(Table 1), coupled with recurring recommendations to control nontarget species in RPS (D'Antonio and Meyerson 2002; Forshay and Morzaria-Luna 2005; Antonsen and Olsson 2005; Fischer and others 2006) underscores the wide-spread and international nature of this phenomenon. Here, we identify multiple factors that might increase the vulnerability of RPS to invasion by nontarget species of concern. Through this synthesis on the vulnerability RPS to invasion by nontarget species of concern, we aim to increase recognition of this problem and promote further investigation of impacts of these species on RPS to secure long-term ecological benefits of conservation practices that aim to improve environmental quality.

\section{Susceptibility to Invasion}

Landscape-, disturbance-, plant community-, and processrelated factors affect the vulnerability of rehabilitated agricultural production systems to invasion by nontarget species (Table 1). These rehabilitated systems often exist as isolated habitats within a matrix of highly modified and managed agricultural landscapes. Surrounding agricultural systems can harbor many nontarget species that can spread to colonize noncropping systems (Johnson and others 2006; Seabloom and others 2006; Smith and others 2006), and increased connectivity of improved or natural areas within these landscapes has been shown to slow the spread of nontarget species (Alard and others 1994; Donald and Evans 2006). For example, colonization and persistence of invasive shrub species have been correlated with historical agricultural land use (Johnson and others 2006; DeGasperies and Motzkin 2007). Furthermore, Clements and others (2004) documented significant within- and among-population genetic variability in traits related to invasiveness of agricultural weeds and proposed that the potential for rapid evolution of invasive traits exists in agriculturally dominated landscapes.

Alterations (i.e., cultivation of soil, replacement of natural plant communities with monocultures of crops, water diversions, herbicide carryover, etc.) to the environment where RPS commonly occur can present a legacy of disturbance outside the natural range of variation to which native historical species are adapted (Table 1). These altered environmental conditions may be less suited to support historical or target communities (Graham and Hutchings 1988; Bakker and others 1991; Galatowitsch and van der Valk 1996). As a result, RPS may not include all of the species, processes, or spatial scales that may be key to resisting invasion (Naeem and others 2000; Sheley and Krueger-Mangold 2003).

Disturbance can further promote invasion by generating space and resources for new species to capitalize (Elton 
Table 1 Synthesis of factors related to increased vulnerability of rehabilitated production systems to invasion by nontarget species of concern

\begin{tabular}{llll}
\hline $\begin{array}{l}\text { Vulnerability } \\
\text { factor }\end{array}$ & $\begin{array}{l}\text { Aspect of } \\
\text { vulnerability } \\
\text { factor }\end{array}$ & Evidence from rehabilitated production systems & Reference(s) \\
& & & \\
\hline
\end{tabular}

Landscape

Fragmentation

Historical land-use

Disturbance legacies

Community structure

Low diversity

High nutrient availability

Altered Hydrology

Altered processes

\section{Exotic/nontarget species \\ Resistance to improved structure}

Nutrient availability and cycling

Management
Increased landscape connectivity slows spread of invasive species.

Maintenance of improved grasslands in intensive agriculture landscape requires connectivity with species rich grasslands.

Occurrence, abundance and spread of invasive shrub related to historical agricultural land-use.

The most influential factor affecting the colonization Johnson and others (2006) and spread of invasive shrubs was proximity to historical and present agricultural fields in the landscape.

Seed banks of fewer target species, lower density of target species, and/or abundance of nontarget species limit rehabilitation of arable lands.

Altered water regimes can result in unexpected (nontarget) community establishment during restoration, resistant to change.

Broad scale hydrologic constraints limit success of rehabilitation target structure and function of bottomland forests.

Non target species of concern more prevalent in rehabilitated systems where nutrient availability is high resulting from past agricultural disturbance, reducing soil fertility increases target species and/or target plant diversity by limiting establishment of nontarget species.

Rehabilitated/restored systems contain lower diversity than native remnant systems.

Higher exotic species diversity in rehabilitated grasslands relative to remnants.

Formerly cultivated systems planted to invasive exotic species resistant to efforts to improve native species diversity.

Establishment of nonnative grasses alters nutrient transformations, availability, and/or storages of organic matter and nutrients.

Attaining target community structure of species-poor grassland established following long-term cultivation is improved with active management that mirrors historical ecosystem drivers.
Donald and Evans (2006)

Alard and others (1994)

DeGasperies and Motzkin (2007)

Graham and Hutchings (1988), Bakker and others (1991), Galatowitsch and van der Valk (1996)

Klotzil and Grootans (2001)

King and Keeland (1999)

Green and Galatowitsch 2001, Baer and others (2002), Gough and Marrs (1990), Marrs (1993), Blumenthal and others (2003), Walker and others (2004), Vinton and Goergen (2006)

Galatowitsch and van der Valk (1996), Lesica and DeLuca (1996), Christian and Wilson (1999), Wilson and Partel 2003, Baer and others (2005), Martin and others (2005)

McLachlan and Knispel (2005)

Christian and Wilson (1999), Gendron and Wilson (2007)

Christian and Wilson (1999), Vinton and Goergen (2006)

Antonsen and Olsson (2005), Walker and others (2004), Pywell and others (2007), Chapman and others (2004b)
1958), and RPS commonly possess biotic, physical, hydrologic, and nutrient perturbations that may persist long after rehabilitation. For example, grasslands converted from row-crop agriculture contain minimal legacy of the historic plant community, as well as severely altered soil structure and nutrient status following long-term cultivation (Low 1972; Baer and others 2002; McLauchlan 2006). Moreover, hydrology of agricultural landscapes may be permanently altered due to altered drainage, increased sedimentation and erosion, and decreased infiltration and decreased plant water uptake by annual crops. These changes can constrain rehabilitation of community structure and function (King and Keeland 1999; Klotzil and Grootans 2001). Finally, altered resource availability from surrounding land management, such as excess nutrients and/or water, may produce more subtle forms of disturbance that can constrain community assembly, structure, and function (Davis and others 2000; Stohlgren and others 
2003; Zedler and Kercher 2004; Vinton and Goergen 2006). In rehabilitated agricultural systems, excess nutrients have been invoked as an important mechanism promoting nontarget species persistence (Green and Galatowitsch 2001; Gough and Marrs 1990; Marrs 1993) and reducing nutrient availability has been shown to increase target and reduce nontarget and invasive species in RPS (Baer and others 2002; Blumenthal and others 2004; Walker and others 2004; Vinton and Goergen 2006).

The legacy of disturbance in RPS (e.g., altered soil structure, high available nutrients, permanently modified hydrologic regimes, etc.) may leave vacant or create novel niches for nontarget species to fill in a community. Colonization by native species is likely to be hindered by their low abundance and subsequent dispersal in agricultural landscapes, whereas weedy nontarget species are likely to be abundant and/or widely distributed. Deliberate attempts to restore high plant diversity in rehabilitated grasslands are commonly fraught with difficulty (Kindscher and Tieszen 1998; Baer and others 2005; Polley and others 2005). Furthermore, if incentive programs to improve environmental quality are short in duration (e.g., $<10$ years) then there may not be sufficient time for native community development in some systems comprised of slow growing species (e.g., trees). Rehabilitations are also generally not provided with the full historical complement of species, but rather a few dominant species. If target species establish slowly, then nontarget and invasive species may have a generous window of opportunity to establish and persist. Finally, lack of disturbances (e.g., fire, grazing, and/or hydrologic fluctuations) that historically were critical to promoting cover, dominance, and diversity of native species also may facilitate invasion in RPS (Naeem and others 2000; Pokorny and others 2005, D'Antonio and Chambers 2006).

Several aspects of community structure in RPS may also facilitate invasion and persistence of nontarget species (Table 1). First, rehabilitated agricultural systems often contain lower diversity than historical communities in the US, where agriculture and management for resource use has not persisted as long as in European countries (Gibson 2009). Rehabilitated grasslands in North America contain lower plant diversity (Christian and Wilson 1999; Baer and others 2005; Martin and others 2005; Polley and others 2005) and more nontarget exotic species (McLachlan and Knispel 2005) than grasslands that have never been cultivated in the same regions. Furthermore, rehabilitated systems planted to exotic species are highly resistant to efforts to introduce native species in the US (Bakker and others 2003; Christian and Wilson 1999; Wilson and Partel 2003; Gendron and Wilson 2007), as well as Europe (Crawley and others 1999).

Natural plant communities are often structured by ecological drivers, e.g., fire and grazing, and the absence of these drivers in some RPS may compromise the persistence of target plant communities historically maintained through these processes. Managing RPS for communities that resist invasion represents one of the most important tools in preventing invasion by nontarget species (D'Antonio and Chambers 2006), and in most regions these drivers are imposed through active management. In some instances, treating RPS as "set aside" systems, as opposed to an alternative type of "working land" may compromise the attainment and persistence of target communities. For example, attaining target community structure of species-poor grasslands from long-term intensive agricultural practice in Europe is improved with active management (Antonsen and Olsson 2005; Walker and others 2004; Pywell and others 2007).

Encroachment of woody species can be detrimental to wildlife conservation goals of rehabilitated grasslands (Chapman and others 2004a). Prescribed fire is an effective tool in preventing and managing these nontarget species invasions (Bernardo and others 1988; Ortman and others 1998). Selective grazing has long been recognized as a costeffective, ecologically compatible tool to manage certain nontarget plants, including woody species (Vallentine 1990). Recent evidence suggests that prescribed grazing, especially when combined with prescribed burning in a spatially dynamic approach called patch burning, can reduce nontarget species while improving overall grassland function and suitability for native wildlife habitat (Fuhlendorf and Engle 2001, 2004; Cummings and others 2007). Mowing and haying are common management practices in rehabilitated grasslands and, when timed and applied properly, can eliminate or reduce woody encroachment (DiTommaso 2000). Unlike grazing, mowing is species-nonselective, and if used improperly, can promote plant invasion (DiTommaso 2000). Also, mowing and haying generally fail to functionally substitute for grazing in nutrient cycling (McNaughton 1984; Ruess and McNaughton 1987, Anderson and others 2006) that might play a pivotal role in ecosystem resistance to invasion (Davis and others 1998; Knops and Tilman 2000; Baer and others 2003).

Using cultural practices that act as ecological drivers is limited to appropriate sites, and less is known about the interaction between invasive and native species in response to these practices (CAST 2003; Langeland and Stocker 1997). For example, fire and grazing may be successful management practices if nontarget species do not share a common evolutionary history with these ecological processes or if species are functionally different from the native constituents (MacDougall and Turkington 2005; D'Antonio and Chambers 2006). Alternatively, invaders that are functionally similar to native species (e.g., phenology and photosynthetic pathways) may respond similarly to management practices as native species, representing a real dilemma for managers (Reed and others 2005). 


\section{Uncertainties Regarding Nontarget Species and Rehabilitation Goals}

If nontarget species colonizing rehabilitated agricultural systems are also invasive, then the goals of rehabilitation efforts may be compromised. Goals regarding restoration of ecosystem services such as sequestering carbon (Lal 2004), improving soil and water quality (Davie and Lant 1994; Baer and others 2002), and increasing connectivity and quality of wildlife habitat (Reynolds and others 2001) may be particularly vulnerable because species differentially affect inputs, storage, and fluxes of nutrients in ecosystems. For example, invasion of grasslands by woody species alters carbon allocation to greater aboveground storage (Norris and others 2001). Invasive species may also alter multiple aspects of carbon cycling through differences in aboveground net primary productivity and root distribution (Wilsey and Polley 2006). Furthermore, modifications to nutrient pools and fluxes by invading species can promote the persistence of these species through feedback mechanisms (Ehrenfeld 2003; Vinton and Goergen 2006), particularly if invading species are capable of nitrogen fixation (Vitousek and others 1987; Rice and others 2004; Baer and others 2006).

If nontarget species in RPS are invasive, these species may also compromise goals of improving plant diversity. Lessons from ecological invasions demonstrate that invaded plant communities often exhibit lower species diversity than uninvaded communities (Levine and others 2003). Although it is often unclear whether an invasive species causes declines in diversity, invades as a result of low diversity, or capitalizes on conditions that negatively impact other species (MacDougall and Turkington 2005), removal of an invasive species usually results in an increase in native species abundance and/or diversity (e.g., Farnsworth and Meyerson 1999; Hulme and Bremner 2006). Exceptions to this response occur when the invasive species leaves a legacy of physical, chemical, or biological alterations to the environment. For example, crested wheatgrass (Agropyron cristatum L.) changes the soil microbial community such that it is more favorable for growth of other invasive species than for native species (Jordan and others 2008).

Not all rehabilitations aim to improve biodiversity. For example, the primary goal of the USDA Conservation Reserve Program was to reduce soil loss from highly eroded cultivated lands (Baker 2000), as reflected by the widespread plantings of exotic species, many of which are invasive (Lesica and DeLuca 1996; White and Dewald 1996; Harmoney and others 2004). Several southern Great Plains states in the US were seeded to vast areas of Old World bluestem (Bothriochloa ischaemum [L.] Keng) varieties cultivated to compete vigorously with native species (Dabo and others 1988; Belesky and Fedders 1995; Harmoney and Hickman 2004). Furthermore, species poor grasslands dominated by exotic species in the US are highly resistant to changes in composition (Bakker and others 2003; Wilson and Partel 2003; Gendron and Wilson 2007). Initiating restorations with native species can constrain invasion (Bakker and Wilson 2004) and increasing use of native species and options to select higher diversity seed mixes in US landowner incentive programs represents a progressive change in program directives with potential benefits to biological diversity.

\section{Summary and Conclusions}

As the global environment becomes increasingly converted and managed for human resource use, we will gradually depend more on rehabilitations of production lands for conservation of resources, biodiversity, and ecosystem functions. Biological invasions are now considered a major global change phenomenon (Vitousek and others 1996). Increased concern about threats invasive species pose to biodiversity, productivity, ecosystem services, human welfare, and the economy in nonproduction systems has recently provoked recommendations to improve prevention, adopt scientificbased risk assessment, increase surveillance and information sharing, provide support for early control, protect uninvaded systems, and coordinate policy (Lodge and others 2006). We demonstrate that RPS are also highly vulnerable to invasion due to landscape factors, legacies of disturbance, novel plant communities, and the absence of ecological drivers that historically maintained target communities. However, there are few examples and subsequently great uncertainty surrounding whether nontarget species of concern compromise the long term goals of rehabilitation efforts towards improving biodiversity and/or ecosystem services in former agricultural production systems.

Acknowledgments This synthesis is a product from the Invasive Plant Species and the 2007 Farm Bill Workshop (March 20-21, 2007) that was organized and supported by the Center for Invasive Plant Management, Bozeman, Montana. We are grateful for the time and effort contributed by M. Johnson and J. Clark towards organizing the agenda, discussion, and outcome of this workshop. Lawrence D. Igl, T. Shaffer, Ryan P. Klopf, Virginia H. Dale, Gregory Houseman, and three anonymous reviewers provided constructive comments towards this manuscript.

\section{References}

Alard D, Bance JF, Frileux PN (1994) Grassland vegetation as an indicator of the main agroecological factors in a rural landscape: consequences for biodiversity and wildlife conservation in central Normandy (France). Journal of Environmental Management 42(2):91-109 
Anderson RH, Fuhlendorf SD, Engle DM (2006) Soil N availability in tallgrass prairie under the fire-grazing interaction. Rangeland Ecology and Management 59(6):625-631

Anonymous (1994) The habitat scheme of former set-aside land: guidelines for farmers. Ministry of Agriculture, Fisheries and Food. London, United Kingdom

Antonsen H, Olsson PA (2005) Relative importance of burning, mowing and species translocation in the restoration of a former boreal hayfield: responses of plant diversity and the microbial community. Journal of Applied Ecology 42(2):337-347

Baer SG, Kitchen DJ, Blair JM, Rice CW (2002) Changes in ecosystem structure and function along a chronosequences of restored grasslands. Ecological Applications 12(6):1688-1701

Baer SG, Blair JM, Collins SL, Knapp AK (2003) Soil resources regulate diversity and productivity in newly established prairie. Ecology 84(3):724-735

Baer SG, Collins SL, Blair JM, Knapp AK, Fiedler A (2005) Soil heterogeneity effects on tallgrass prairie community heterogeneity: an application of ecological theory to restoration ecology. Restoration Ecology 13(2):413-424

Baer SG, Church JM, Williard KWJ, Groninger JW (2006) Changes in intrasystem $\mathrm{N}$ cycling from N2-fixing shrub encroachment in grassland: multiple positive feedbacks. Agriculture. Ecosystems and Environment 115(1-4):174-182

Baker B (2000) Farm Bill environmental program may threaten native prairie habitat. BioScience 50(5):400

Bakker JD, Wilson SD (2004) Using ecological restoration to constrain biological invasion. Journal of Applied Ecology 41(6): 1058-1064

Bakker JD, Bos AF, Hoogveld J, Muller HJ (1991) The role of seedbank in restoration and management of semi-natural grasslands. In: Ravera $\mathrm{O}$ (ed) Terrestrial and aquatic ecosystems: perturbation and recovery. Ellis Horwood, New York, pp 449 455

Bakker JD, Wilson SD, Christian JM, Li X, Ambrose LG, Waddington J (2003) Contingency of grassland restoration on year, site, and competition from introduced grasses. Ecological Applications 13(1): 137-153

Belesky DP, Fedders JM (1995) Warm-season grass productivity and growth rate as influenced by canopy management. Agronomy Journal 87(6):42-48

Bernardo DL, Engle DM, McCollum FT (1988) An economic assessment of risk and returns from prescribed burning on tallgrass prairie. Journal of Range Management 41(2):178-183

Blumenthal DM, Jordan NR, Russelle MP (2003) Soil carbon addition controls weeds and facilitates prairie restoration. Ecological Applications 13(3):605-615

Bradshaw AD (1996) Underlying principles of restoration. Canadian Journal of Fisheries and Aquatic Sciences 53(Supplement):3-9

CAST (2003) Integrated pest management: current and future strategies. Task force report No 140 Ames, Council for Agricultural Science and Technology, IA

Chapman RN, Engle DM, Masters RE, Leslie DM Jr (2004a) Tree invasion constrains the influence of herbaceous structure in grassland bird habitats. Ecoscience 11(1):55-63

Chapman RN, Engle DM, Masters RE, Leslie DM Jr (2004b) Grassland vegetation and bird communities in the southern Great Plains of North America. Agriculture. Ecosystems and Environment 104(3):577-585

Christian JM, Wilson SD (1999) Long-term ecosystem impacts of an introduced grass in the northern Great Plains. Ecology 80(7):2397-2407

Clements DR, DiTommaso A, Jordan N, Booth BD, Cardina J, Doohan D, Mohler CL, Murphy SD, Swanton CJ (2004) Adaptability of plants invading North American cropland. Agriculture. Ecosystems and Environment 104(3):379-398
Crawley MJ, Brown SL, Heard MS, Edwards GR (1999) Invasionresistance in experimental grassland communities: species richness or species identity? Ecology Letters 2(1):140-148

Cummings DC, Fuhlendorf SD, Engle DM (2007) Is altering grazing selectivity of invasive forage species with patch burning more effective than herbicide treatments? Rangeland Ecology and Management 60(3):253-260

D'Antonio CM, Chambers JC (2006) Using ecological theory to manage or restore ecosystems affected by invasive plant species. In: Falk DA, Palmer MA, Zedler JB (eds) Foundations of Restoration Ecology. Island Press, Washington, DC, pp 260279

D'Antonio CM, Meyerson LA (2002) Exotic plant species as problems and solutions in ecological restoration: a synthesis. Restoration Ecology 10(4):703-713

D'Antonio CM, Vitousek PM (1992) Biological invasions by exotic grasses, the grass/fire cycle, and global change. Annual Review of Ecology and Systematics 23:63-87

Dabo SM, Taliaferro CM, Coleman SW, Horn FP, Claypool PL (1988) Chemical composition of old world bluestem grasses as affected by cultivar and maturity. Journal of Range Management 41(1):40-48

Davie DK, Lant CL (1994) The effect of CRP enrollment on sediment loads in 2 southern Illinois streams. Journal of Soil and Water Conservation 49(4):407-412

Davis MA, Wrage KJ, Reich PB (1998) Competition between tree seedlings and herbaceous vegetation: support for a theory of resource supply and demand. Journal of Ecology 86(4):652-661

Davis MA, Grime JP, Thompson K (2000) Fluctuating resources in plant communities: a general theory of invisibility. Journal of Ecology 88(3):528-534

DeGasperis BG, Motzkin G (2007) Windows of opportunity: historical and ecological controls on Berberis thunbergii invasions. Ecology 88(12):3115-3125

DiTommaso JM (2000) Invasive weeds in rangelands: species, impacts, and management. Weed Science 48(2):255-265

Donald PF, Evans AD (2006) Habitat connectivity and matrix restoration: the wider implications of agri-environment schemes. Journal of Applied Ecology 43(2):209-218

Dunn CP, Stearns F, Guntenspergen GR, Sharpe DM (1993) Ecological benefits of the Conservation Reserve Program. Journal of Soil and Water Conservation 7(1):132-139

Ehrenfeld JG (2003) Effects of exotic plant invasions on soil nutrient cycling processes. Ecosystems 6(6):503-523

Elton C (1958) The ecology of invasions by plants and animals. Metheun, London

Farnsworth EJ, Meyerson LA (1999) Species composition and interannual dynamics of a freshwater tidal plant community following removal of the invasive grass, Phragmites australis. Biological Invasions 1(2-3):115-127

Fischer J, Lindenmayer DB, Manning AD (2006) Biodiversity, ecosystem function, and resilience: ten guiding principles for commodity production landscapes. Frontiers in Ecology and the Environment 4(2):80-86

Forshay KJ, Morzaria-Luna HN, Hale B, Predick K (2005) Landowner satisfaction with the wetlands reserve program. Environmental Management 36(2):248-257

Fuhlendorf SD, Engle DM (2001) Restoring heterogeneity on rangelands: ecosystem management based on evolutionary grazing patterns. BioScience 51(8):625-632

Fuhlendorf SD, Engle DM (2004) Application of the fire-grazing interaction to restore a shifting mosaic on tallgrass prairie. Journal of Applied Ecology 41(4):604-614

Galatowitsch SM, van der Valk AG (1996) The vegetation of restored and natural prairie wetlands. Ecological Applications 6(1):102112 
Gendron F, Wilson SD (2007) Responses to fertility and disturbance in a low diversity grassland. Plant Ecology 191(2):199-207

Gibson DJ (2009) Grasses and grassland ecology. Oxford University Press, Oxford

Gough MW, Marrs RH (1990) A comparison of soil fertility between semi-natural and agricultural plant communities: implications for the creation of species-rich grassland on abandoned agricultural land. Biological Conservation 51(1):83-96

Graham DJ, Hutchings MJ (1988) Estimation of the seed bank of a chalk grassland ley established on former arable land. Journal of Applied Ecology 25(2):241-252

Green EK, Galatowitch SM (2001) Differences in wetland plant community establishment with additions of nitrate- $\mathrm{N}$ and invasive species (Phalaris arundinacea and Typha xglauca). Canadian Journal of Botany 79(2):170-178

Harmoney KR, Hickman KR (2004) Comparative morphology of Caucasian Old World bluestem and native grasses. Agronomy Journal 96(6):1540-1544

Harmoney KR, Stahlman PW, Hickman KR (2004) Herbicide effects on established yellow Old World bluestem (Bothriochloa ischaemum). Weed Technology 18(3):545-550

Hulme PE, Bremner ET (2006) Assessing the impact of Impatiens glandulifera on riparian habitats: partitioning diversity components following species removal. Journal of Applied Ecology 43(1):43-50

Johnson VS, Litvaitis JA, Lee TD, Frey SD (2006) The role of spatial and temporal scale in colonization and spread of invasive shrubs in early successional habitats. Forest Ecology and Management 228(1-3):124-134

Jordan NR, Larson DL, Huerd SC (2008) Soil modification by invasive plants: effects on native and invasive species of mixedgrass prairies. Biological Invasions 274(3):248-253

Kindscher K, Tieszen LL (1998) Floristic and soil organic matter changes after five and twenty-five years of native tallgrass prairie restoration. Restoration Ecology 6(2):181-196

King SL, Keeland BD (1999) Evaluation of reforestation in the lower Mississippi River Alluvial Valley. Restoration Ecology 7(4):348-359

Klotzil F, Grootans AP (2001) Restoration of natural and semi-natural wetland systems in Central Europe: progress and predictability of development. Restoration Ecology 9(2):209-219

Knops JMH, Tilman D (2000) Dynamics of soil nitrogen and carbon accumulation for 61 years after agricultural abandonment. Ecology 81(1):88-98

Lal R (2004) Agricultural activities and the global carbon cycle. Nutrient Cycling in Agroecosystems 70(2):103-116

Langeland KA, Stocker RK (1997) Control of nonnative plants in natural areas of Florida, SP242. University of Florida, Institute of Food and Agricultural Sciences, Gainesville

Lesica P, DeLuca TH (1996) Long-term harmful effects of crested wheatgrass on Great Plains grassland ecosystems. Journal of Soil and Water Conservation 51(5):408-409

Levine JM, Vila M, D'Antonio CM, Dukes JS, Grigulis K, Lavorel S (2003) Mechanisms underlying the impacts of exotic plant invasions. Proceedings of The Royal Society Of London Series B-Biological Sciences 270(1517):775-781

Lodge DM, Williams S, MacIssac HJ, Hayes KR, Leung B, Reichard S, Mack RM, Moyle PB, Smith M, Andow DA, Carlton JT, McMichael A (2006) Biological invasions: recommendations for US policy and management. Ecological Applications 16(6):2035-2054

Low AJ (1972) The effect of cultivation on the structure and other physical characteristics of grassland and arable soils. Journal of Soil Science 23(3):363-380

MacDougall AS, Turkington R (2005) Are invasive species the drivers or passengers of change in degraded ecosystems? Ecology 86(1):42-55
Mack RN, Simberloff D, Lonsdale WM, Evans H, Clout M, Bazzaz FA (2000) Biotic invasions: causes, epidemiology, global consequences, and control. Ecological Applications 10(3):689710

Marrs RH (1993) Soil fertility and nature conservation in Europe: theoretical considerations and practical management solutions. Advances in Ecological Research 24:241-300

Marrs RH, Galtress K, Tong C, Cox ES, Blackbird SJ, Heyes TJ, Pakeman RJ, Le Duc MG (2007) Competing goals, biodiversity or ecosystem services: element losses and species recruitment in a managed moorland-bracken model system. Journal of Environmental Management. 85(4):1034-1047

Martin LM, Moloney KA, Wilsey BJ (2005) An assessment of grassland restoration success using species diversity components. Journal of Applied Ecology 42(2):327-336

McLachlan SM, Knispel AL (2005) Assessment of long-term tallgrass prairie restoration in Manitoba, Canada. Biological Conservation 124(1):75-88

McLauchlan K (2006) The nature and longevity of agricultural impacts on soil carbon and nutrients: a review. Ecosystems 9(8):1364-2900

McNaughton SJ (1984) Grazing lawns-animals in herds, plant form, and coevolution. American Naturalist 124(6):863-886

Naeem S, Knops JMH, Tilman D, Howe KM, Kennedy T, Gale S (2000) Plant diversity increases resistance to invasion in the absence of covarying extrinsic factors. Oikos 91(1):97-108

Norris MD, Blair JM, Johnson LC, McCane RB (2001) Assessing changes in biomass, productivity, and $\mathrm{C}$ and $\mathrm{N}$ stores following Juniperus virginiana forest expansion into tallgrass prairie. Canadian Journal of Forest Research 31(11):1940-1946

Ortmann J, Stubbendieck J, Masters RA, Pfeiffer GH, Bragg TB (1998) Efficacy and costs of controlling eastern redcedar. Journal of Range Management 51(2):158-163

Pimentel D (ed) (2002) Biological Invasions: economic and Environmental Costs of Alien Plant, Animal, and Microbe Species. CRC Press, Boca Raton, FL

Pimentel D, Lach L, Zuniga R, Morrison D (2000) Environmental and economic costs of nonindigenous species in the United States. BioScience 50(1):53-65

Pokorny M, Sheley RL, Zabinski C, Engel R, Svejcar A, Borkowski J (2005) Plant functional group diversity as a mechanism for invasion resistance. Restoration Ecology 13(1):1-12

Polley HW, Derner JD, Wilsey BJ (2005) Patterns of plant species diversity in remnant and restored tallgrass prairies. Restoration Ecology 13(3):480-487

Pywell RF, Bullock JM, Tallowin B, Walker KJ, Warman EA, Masters G (2007) Enhancing diversity of species poor grasslands: an experimental assessment of multiple constraints. Journal of Applied Ecology 44(1):81-94

Reed HE, Seastedt TR, Blair JM (2005) Ecological consequences of $\mathrm{C}-4$ grass invasion of a $\mathrm{C}-4$ grassland: a dilemma for management. Ecological Applications 15(5):1560-1569

Reynolds RE, Shaffer TL, Renner RW, Newton WE, Batt BDJ (2001) Impact of the conservation reserve program on duck recruitment in the US Prairie Pothole Region. Journal of Wildlife Management 65(4):765-780

Rice SK, Westerman B, Federici R (2004) Impacts of the exotic, nitrogen-fixing black locust (Robinia pseudoacacia) on nitrogencycling in a pine-oak ecosystem. Plant Ecology 147(1):97-107

Ruess RW, McNaughton SJ (1987) Grazing and the dynamics of nutrient and energy regulated microbial processes in the Serengeti grasslands. Oikos 49(1):101-110

Seabloom EW, Williams JH, Slayback D, Stoms DM, Viers JH, Dobson DP (2006) Human impact, plant invasion, and imperiled plant species in California. Ecological Applications 16(4):13381350 
Sheley RL, Krueger-Mangold J (2003) Principles for restoring invasive plant-infested rangeland. Weed Science 51(2):260-265

Smith RG, Maxwell B, Menalled FD, Rew LJ (2006) Lessons from agriculture may improve the management of invasive plants in wildland systems. Frontiers in Ecology and the Environment 4(8):428-434

Stohlgren TJ, Barnett DT, Kartesz J (2003) The rich get richer: patterns of plant invasions in the United States. Frontiers in Ecology and the Environment 1(1):11-14

Suding KN, Gross KL, Houseman GR (2004) Alternative states and positive feedbacks in restoration ecology. Trends in Ecology \& Evolution 19(1):46-53

Vallentine JF (1990) Grazing management. Academic Press, Inc, San Diego

Vinton MA, Goergen EM (2006) Plant-soil feedbacks contribute to the persistence of Bromus inermis in tallgrass prairie. Ecosystems 9(6):967-976

Vitousek PM, Walker LR (1989) Biological invasion by Myrica faya in Hawaii: plant demography, nitrogen fixation, ecosystem effects. Ecological Monographs 59(3):247-265
Vitousek PM, Walker LR, Whiteaker LD, Mueller-Dombois D, Matson PA (1987) Biological invasion by Myrica faya alters ecosystem development in Hawaii. Science 238(4828):802-804

Vitousek PM, D’Antonio CM, Loope LL, Westbrooks R (1996) Biological invasions as global environmental change. American Scientist 84(5):468-478

Walker KJ, Stevens PA, Stevens DP, Mountford JO, Manchester SJ, Pywell RF (2004) The restoration of species-rich grassland on land formerly managed for intensive agriculture in the UK. Biological Conservation 119(1):1-18

White LM, Dewald CL (1996) Yield and quality of WW-Iron Master and Caucasian bluestem regrowth. Journal of Range Management 49(1):42-45

Wilsey BJ, Polley HW (2006) Aboveground productivity and rootshoot allocation differ between native and introduced grass species. Oecologia 150(2):300-309

Zedler JB, Kercher S (2004) Causes and consequences of invasive plants in wetlands: opportunities, opportunists, and outcomes. Critical Reviews in Plant Sciences 23(5):431-452 